\title{
AN INEQUALITY OF OSTROWSKI TYPE AND ITS APPLICATIONS FOR SIMPSON'S RULE AND SPECIAL MEANS
}

\author{
I. FEDOTOV AND S. S. DRAGOMIR
}

Abstract. An integral inequality of Ostrowski type and its applications for special means and error evaluation in Simpson's quadrature rule are given.

Mathematics subject classification (1991): 26D15, 41A55.

Key words and phrases: Ostrowski inequality, Simpson's rule..

\section{REFERENCES}

[1] S.S. DRAGOMIR AND S. WANG, An inequality of Ostrowski-Grüss' type and its applications to the estimations of error bounds for some special means and for some numerical quadrature rules, Computing Math. Appl. 33(11) (1997), 15-20.

[2] D.S. Mitrinović, J.E. PeČARIĆ AND A.M. FinK, Classical and New Inequalities in Analysis, Kluwer Academic Publishers, 1993.

[3] D.S. Mitrinović, J.E. PEČARIĆ AND A.M. FinK, Inequalities for Functions and Their Integrals and Derivatives, Kluwer Academic Publishers, 1994. 